\title{
RANCANGAN KABIN MASINIS KRL COMMUTER LINE DENGAN METODE QUICK EKSPOSURE CHECK (QEC) DAN ANTROPOMETRI
}

\author{
Nurfajriah $^{1}$, Djodi Erlangga ${ }^{2}$ \\ Program Studi Teknik Industri, Universitas Pembangunan Nasional "Veteran” Jakarta, Jakarta Selatan ${ }^{1}$ \\ Mahasiswa Fakultas Teknik, Program Studi Teknik Industri, Universitas Pembangunan Nasional "Veteran” \\ Jakarta, Jakarta Selatan ${ }^{2}$ \\ email $^{1}$ : nurfajriahzhia@gmail.com
}

\begin{abstract}
Unergonomic working condition for driving cabin in Commuter train (KRL) can cause a machinist to be exposed to work-related Musculoskeletal Disorder (WMSDs)which affects the diminished of concentration capabilities when operating KRL which tends to be static. Research conducted with the aim to give the best design of steeringroom, both from chair and cabin size and the placement of controller and monitor screen insntrumen that can accommodate the machinist work posture to avoid WMSDs. The research was conducted by analyzing the driver's posture using the Quick Exposure Checklist (QEC) method. Based on the calculation of total final score of exposure and level of action obtained from samples that worked driver machinary still vary and all result of action level obtained show 58 engineer experiencing level 3 exposure with action that need to be done is action in the near future which means action need to be done as soon as possible and 2 machinists having level 4 exposure with the action that needs to be done is action is required now.
\end{abstract}

Keyword : Ergonomic, Anthropometry, Quick Exposure

\section{PENDAHULUAN}

Kereta Listrik belakangan ini menjadi primadona di kalangan masyarakat dan pemerintah karena dinilai sebagai moda transportasi massal yang efektif dalam mengatasi permasalahan kemacetan di ibukota yang sangat kompleks. Hal ini dibuktikan dengan upaya pemerintah dalam pembangunan infrastruktur perkeretaapian baru seperti Mass Rapid Transit (MRT) dan Light Rapid Transit (LRT), serta peningkatan pelayanan dan perluasan jalur pemberhentian Kereta Rel Listrik (KRL) Commuter Line yang dilakukan PT. KAI Commuter line Jabodetabek (KCJ) sebagai kereta angkutan massal dalam kota pertama yang ada di Indonesia sejak tahun 1925.

PT. KCJ telah berhasil mengubah citra angkutan yang sebelumnya memiliki citra semerawut dengan melakukan berbagai revolusi seperti penambahan unit KRL, penerapan ETicketing dan sistem tarif progresif dengan penghapusan KRL ekspres, penerapan kereta khusus wanita, dan mengubah nama KRL ekonomiAC menjadi kereta Commuter Line yang dilanjutkan dengan renovasi, penataan ulang, dan sterilisasi sarana dan prasarana termasuk jalur kereta dan stasiun kereta yang dilakukan bersama PT. KAI (persero) dan Pemerintah. Sayangnya perbaikan sarana dan prasarana fasilitas KRL
Commuter Line untuk penumpang saat ini masih tidak beriringan dengan upaya perbaikan kenyamanan fasilitas untuk pegawai khususnya masinis yang berperan dalam mengoperasikan dan menjalankan KRL tersebut.

Beberapa seri kabin KRL didesain dengan hanya satu kursi untuk masinis sehingga seorang asisten masinis harus berdiri atau membawa kursi tambahan saat mendampingi masinis. Kursi masinis dibuat sangat sederhana tanpa sandaran yang layak dengan tujuan agar dapat di lipat guna memudahkan teknisi untuk melakukan perawatan di ruang kabin. Selain itu di dalam kabin juga terdapat berbagai panel instrumen seperti tuas, tombol - tombol serta display yang di tata cukup jauh untuk di jangkau seorang masinis dalam keadaan duduk. Sehingga hal ini membuat seorang masinis harus sering berdiri atau bersusah payah dalam menggapai panel instrument di dalam kabin KRL tersebut.

Penelitian ini bertujuan untuk melakukan evaluasi lingkungan kabin masinis KRL Commuter Line dengan penerapan kaidah ergonomi dengan menciptakan desain kabin masinis yang nyaman di gunakan oleh penugasan masinis tunggal serta nyaman digunakan saat di damping oleh asisten masinis ataupun teknisi. 


\section{TINJAUAN PUSTAKA}

\section{Ergonomi}

Ergonomi merupakan kata yang berasal dari bahasa Yunani yang terdiri dari "ergon" yang berarti kerja dan "nomos" yang berarti hukum. International Ergonomics Association mendefinisikan ergonomi sebagai disiplin ilmu yang menjelaskan tentang interaksi antara manusia dan elemen - elemen lain dalam sistem dan profesi yang menerapkan teori, prinsip, data, dan metode untuk mendesain sesuatu dalam rangka mengoptimalkan kesejahteraan manusia dan kinerja sistem secara keseluruhan.

Secara khusus ergonomi mempelajari keterbatasan dan kemampuan manusia dalam berinteraksi dengan lingkungan kerja beserta peralatan, produk, dan fasilitas yang digunakan sehari-hari, dalam rangka menyesuaikan lingkungan kerja dan peralatan tersebut

agar lebih sesuai dengan kebutuhan dan batas kemampuan manusia (Mark Sanders, Ernest McCormick, 1993).

Tujuan dari ergonomi adalah untuk memperbaiki performa sistem dengan memperbaiki interaksi antara manusia dengan mesin. Hal ini dapat dilakukan dengan membuat interface yang lebih baik atau dengan menghilangkan faktor dalam lingkungan kerja, tugas, atau organisasi yang dapat menurunkan performa manusia pada saat mengoperasikan mesin. Sistem dapat diperbaiki dengan:

a Merancang user-interface menjadi lebih kompatibel dengan tugas dan pengguna. Hal ini dapat membuat mesin tersebut lebih mudah digunakan dan lebih tahan terhadap kesalahan yang manusia lakukan.

b Merubah lingkungan kerja menjadi lebih aman dan lebih sesuai dengan tugas

c Merubah tugas menjadi lebih kompatibel dengan karakteristik pengguna.

d Merubah cara bekerja menjadi lebih terorganisi untuk dapat mengakomodasi psikologi manusia dan kebutuhan sosial.

Implementasi ergonomi dalam perancanga sistem dapat membuat system bekerja lebih baik dengan menghilangkan aspek sistem berfungsi tidak sesuai dengan keinginan, tidak terkendali, atau tidak dapat dijelaskan, seperti:

a Tidak efisien - ketika usaha pekerja menghasilkan hasil yang tidak optimal

b Fatigue - rancangan kerja yang buruk mengakibatkan pekerja mudah kelelahan

c Kecelakaan, cidera, dan kesalahan dalam kaitannya dengan rancangan interface yang buruk dan atau stres yang berlebihan baik pada mental atau jasmani

d Berbagai kesulitan pengguna - berkaitan dengan kombinasi tugas-tugas yang tidak tepat menghasilkan interaksi yang sulit digunakan dan tidak wajar

e. Semangat juang yang rendah dan kelesuan

\section{Quick Exposure Check (QEC)}

Quick Exposure Checklist (QEC) merupakan checklist yang memiliki tingkat sensitivitas dan kegunaan yang tinggi, QEC diterima secara luas oleh para peneliti dan memiliki tingkat keandalan yang cukup tinggi. Hasil studi menunjukkan bahwa QEC dapat diaplikasikan untuk berbagai macam tugas. Selain itu, QEC juga mampu memberikan evaluasi terhadap tempat kerja, perancangan peralatan dan fasilitas.

Penilaian postur kerja dengan metode QEC dilakukan dari dua sisi. Penilaian pertama didasarkan kepada penilaian pengamat (Observer's Assessment) dengan mengisi Observer's Assessment Checklist dan penilai kedua didasarkan kepada penilai pekerja (Worker's Assessment) dengan mengisi Worker's Assessment Checklist. QEC sistem ini menilai gangguan resiko yang terjadi pada bagian belakang punggung (back), bahu/lengan (should/arm), pergelangan tangan (hand/wrist), dan leher (neck).

Selanjutnya perhitungan skor penilaian untuk masing - masing bagian tubuh yang dinilai dengan tabel skor penilaian sebagai skor akhir QEC untuk diwujudkan dalam empat tingkatan tindakan. Penilaian QEC mendorong pertimbangan untuk merubahan workstation atau stasiun kerja, peralatan, perlengkapan dan metode kerja untuk menghilangkan, atau setidaknya meminimalkan, tingkat paparan. Hal ini harus dilakukan dalam diskusi langsung dengan operator dari stasiun kerja tersebut. Mereka yang memiliki keterlibatan langsung dalam melaksanakan pekerjaannya mungkin memiliki saran yang baik untuk peningkatan perbaikan. Konsultasi pada tahap ini akan membantu pengenalan perubahan di tempat kerja. Ketika perubahan telah dibuat, paparan harus kembali dinilai untuk memastikan efektifitas intervensi dalam mengurangi faktor risiko musculoskeletal disorders.

Tabel 1. Nilai Level Tindakan Perhitungan QEC

\begin{tabular}{cccc}
\hline Level Tindakan & $\begin{array}{c}\text { Persentase } \\
\text { Skor }\end{array}$ & Tindakan & $\begin{array}{c}\text { Total Skor } \\
\text { Exposur }\end{array}$ \\
\hline 1 & $0-40$ & Aman & $32-70$ \\
2 & $41-50$ & Diperlukan beberapa waktu ke depan & $71-88$ \\
3 & $51-70$ & Tindakan dalam waktu dekat & $89-123$ \\
4 & $71-100$ & Tindakan sekarang juga & $124-176$ \\
\hline \multicolumn{2}{l}{ Sumber. Li and Buckle, 1998 } &
\end{tabular}

\section{Antropometri}

Antropometri merupakan bagian dari ergonomi yang secara khusus mempelajari ukuran tubuh yang meliputi dimensi linier, berat, isi, 
meliputi juga ukuran, kekuatan, kecepatan dan aspek lain dari gerakan tubuh. Antropometri berasal dari bahasa Yunani yang berasalah dari kata "anthro" yang berarti manusia dan "metri" yang berarti ukuran. Sehingga dapat dikatakan bahwa antropometri merupakan suatu studi yang berkaitan dengan pengukuran dimensi manusia. Menurut Stevenson (1989) dan Nurmianto (1991), Antropometri adalah satu kumpulan data numerik yang berhubungan dengan karakteristik disik tubuh manusia ukuran, bentuk, dan kekuatan serta penerapan dari data tersebut untuk penanganan masalah desain. Antropometri secara luas akan digunakan sebagai pertimbangan - pertimbangan ergonomis dalam memerlukan interaksi manusia.

Data antropometri yang berhasil diperoleh akan diaplikasikan secara luas, antara lain :

a. Perancangan areal kerja

b. Perancangan peralatan seperti mesin, perkakas

c. Perancangan produk konsumtif seperti pakaian, kursi meja komputer

d. Perancangan lingkungan kerja fisik

Dalam kaitan ini maka perancangan produk harus mampu mengakomodasi dimensi tubuh dari populasi terbesar yang akan menggunakan produk hasil rancangan tersebut.

\section{METODOLOGI PENELITIAN}

Metodologi penelitian dilakukan melalui tahapan-tahapan yang disusun secara sistematis. Berikut ini adalah rincian pelaksanaan penelitian mulai dari tahap persiapan hingga penelitian selelsai dilaksanakan.

a. Tahap Persiapan Penelitian

Dalam tahap ini, dilakukan observasi awal untuk mencari permasalahan yang di alami karyawan perusahaan di Depo KRL Depok yang kemudian di angkat sebagai permasalahan yang ingin diteliti serta dianalisis lebih dalam.

b. Tahap Pengumpulan Data

Dalam tahapan ini, dilakukan identifikasi dan pengumpulan data-data yang akan digunakan dalam pengerjaan penelitian. Data yang dibutuhkan adalah data interaksi antara Masinis dan lingkungan kabin KRL Commuter Line yaitu data keluhan otot (musculoskeletal disorders) yang dialami masinis saat mengendarai KRL dengan pengisian Kuisioner Quick Exsposure Checklists (QEC) oleh Masinis dan Pengamat, dan pengukuran sampel dimensi tubuh (antropometri) Masinis / Asisten Masinis menggunakan anthropometer. Tahap pengumpulan data ini dilakukan dengan pengukuran langsung, dokumentasi, wawancara dan kuesioner.

c. Tahap Pengolahan Data
Tahap pengolahan data dilakukan setelah data yang dikumpulkan mencukupi. Di awali pengolahan kuisioner QEC untuk mengetahui seberapa besar dampak resiko cedera otot (musculoskeletal disorders) yang dihadapi masinis KRL. Selanjutnya dengan pengolahan data antropometri masinis menentukan ukuranukuran persentil antropometri yang akan di gunakan sebagai usulan desain.

d. Tahap Analisis Data

Analisis dilakukan berdasarkan hasil QEC yang diperoleh dan desain yang dibuat.

e. Tahap Penarikan Kesimpulan

Berdasarkan analisis yang dibuat dan model simulasi kerja yang telah dirancang, maka keseluruhan penelitian ini dapat disimpulkan untuk kemudian diberikan saran dan masukan yang berguna bagi pihak yang terkait dengan penelitian ini.

\section{Tempat dan Waktu Penelitian}

Pelaksanaan Penelitian dilaksanakan di divisi Interior - Eksterior dan bagian KUPT Kru KA, Depo KRL Depok, PT KAI Commuter Line Jabodetabek yang berlokasi di Kelurahan Ratu Jaya, Kecamatan Pancoran Mas, Kota Depok, Jawa Barat. Observasi awal dilaksanankan pada tanggal 03 - 31 Oktober 2016 dan pengambilan dan pelengkapan data di laksanakan pada tanggal 13, 19 April, dan 13 Mei 2017.

\section{ANALISIS DAN PEMBAHASAN DATA}

KRL JR East seri 205 dipiih menjadi objek pengukuran aktual dalam penelitian dengan pertimbangan bahwa KRL ini merupakan komoditas utama yang paling banyak beroperasi di Commuter Line Jabodetabek. Selain itu KRL JR East seri 205 ini merupakan KRL hasil hibah negara Jepang yang paling mudah untuk di modifikasi dan banyak dijadikan eksperimen oleh PT. KCJ karena komponennya yang mudah untuk di bongkarpasang, dan mempunyai daya yang besar. Eksperimen-eksperimen yang sudah dilakukan pada KRL seri JR East 205 antara lain pengacakan ulang urutan formasi rangkaian hingga dapat ditransformasikan menjadi 12 rangkaian tanpa mengurangi performa KRL, pemprograman ulang papan penunjuk tujuan LCD pada seluruh rangkaian,

pemasangan kamera CCTV dan pemasangan layar LCD pada rangkaian.

\section{Exposure Level dengan Metode QEC}

Untuk mengidentifikasi level tindakan yang harus dilakukan pada postur tubuh masinis yang beresiko terkena Work-related muskuloskeletal disorder (WMSDs) pada saat mengendarai KRL 
Commuter Line digunakan metode QEC. QEC juga mengidentifikasi resiko cedera WMSDs pada pada empat area tubuh yang terpapar saat melaksanakan pekerjaan. Tahapan menggunakan Metode QEC yaitu melakukan penilaian pengamat menggunakan kuesioner scoresheet QEC (checklist) terhadap masinis saat melakukan pekerjaannya, melakukan penilaian operator terhadap sikap ataupun postur kerja yang dirasakan selama bekerja, melakukan perhitungan skor eksposur dengan menggabungkan hasil kuesioner scoresheet QEC pengamat dan operator, mengidentifikasi level tindakan yang diperoleh dari hasil perhitungan skor eksposur.

Tabel 2. Rekapitulasi Perolehan Skor Exposure Penilaian QEC

\begin{tabular}{|c|c|c|c|c|c|c|c|c|c|}
\hline No. & Nama Masinis & 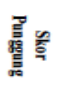 & 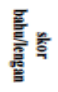 & 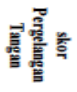 & $\frac{n}{\frac{0}{5}}$ & 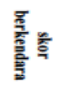 & 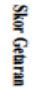 & 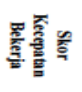 & $\begin{array}{l}\frac{n}{5} \\
\frac{5}{5} \\
\frac{5}{2}\end{array}$ \\
\hline 1 & Kurdianto & 22 & 30 & 22 & 16 & 9 & 9 & 4 & 4 \\
\hline 2 & Hendri sutarto & 22 & 30 & 28 & 16 & 9 & 9 & 4 & 1 \\
\hline 3 & Selamet yudiono & 22 & 30 & 22 & 16 & 9 & 9 & 4 & 4 \\
\hline 4 & Juliandra syarli & 22 & 30 & 22 & 12 & 9 & 9 & 1 & 4 \\
\hline 5 & Amin prayoga & 22 & 30 & 22 & 16 & 9 & 9 & 1 & 4 \\
\hline 6 & Riflyy nur aziz & 22 & 30 & 28 & 16 & 9 & 9 & 4 & 1 \\
\hline 7 & Yusuf fariz aiman & 22 & 30 & 22 & 16 & 9 & 9 & 1 & 1 \\
\hline 8 & Aulia zulfikar & 22 & 30 & 22 & 16 & 9 & 9 & 4 & 4 \\
\hline 9 & M. Iqbal & 22 & 30 & 22 & 16 & 9 & 9 & 4 & 1 \\
\hline 10 & Ari marandika & 22 & 30 & 22 & 16 & 9 & 9 & 1 & 1 \\
\hline 11 & Taufik hidayat & 20 & 30 & 22 & 12 & 4 & 4 & 4 & 4 \\
\hline 12 & Ade surya putra & 22 & 30 & 22 & 16 & 9 & 9 & 4 & 1 \\
\hline 13 & Hafiz daniswara & 22 & 30 & 34 & 16 & 9 & 9 & 4 & 4 \\
\hline 14 & Sealtiel saragih & 22 & 30 & 22 & 16 & 9 & 9 & 1 & 4 \\
\hline 15 & Muhammad rizqi rosyid & 22 & 30 & 22 & 16 & 9 & 9 & 4 & 1 \\
\hline 16 & sobar $\mathrm{m}$ fatoni & 22 & 30 & 22 & 16 & 9 & 9 & 1 & 1 \\
\hline 17 & Andy supriadi & 22 & 30 & 22 & 12 & 9 & 9 & 1 & 1 \\
\hline 18 & Devi yulianto rhahmadi & 22 & 30 & 22 & 12 & 9 & 9 & 1 & 4 \\
\hline 19 & Agus priyanto & 22 & 30 & 22 & 16 & 9 & 9 & 1 & 4 \\
\hline 20 & Rizki eka firdaus & 22 & 30 & 28 & 16 & 9 & 9 & 4 & 4 \\
\hline 21 & Bachtiar mustakim & 22 & 30 & 28 & 16 & 9 & 9 & 4 & 4 \\
\hline 22 & Setiawan kuncoro & 22 & 30 & 22 & 16 & 9 & 9 & 4 & 4 \\
\hline 23 & Feby pratama & 22 & 30 & 22 & 16 & 9 & 9 & 1 & 4 \\
\hline 24 & Ahmad fajni & 22 & 30 & 22 & 16 & 9 & 9 & 4 & 4 \\
\hline 25 & Egit alpino & 22 & 30 & 28 & 16 & 9 & 9 & 4 & 4 \\
\hline 26 & Angga bayu prawira & 22 & 30 & 22 & 16 & 9 & 9 & 4 & 4 \\
\hline 27 & Fathin filkriyansyah & 22 & 30 & 22 & 12 & 9 & 9 & 1 & 1 \\
\hline 28 & Tllam saputro & 22 & 30 & 28 & 16 & 9 & 9 & 1 & 4 \\
\hline 29 & Lustiono & 22 & 30 & 22 & 16 & 9 & 9 & 4 & 1 \\
\hline 30 & Rio pratama a & 22 & 30 & 28 & 16 & 9 & 9 & 4 & 4 \\
\hline 31 & M. fajar mujaddid & 22 & 30 & 22 & 16 & 9 & 9 & 1 & 4 \\
\hline 32 & Bambang sujono & 22 & 30 & 28 & 16 & 9 & 9 & 4 & 4 \\
\hline 33 & Heriyanto hadi nugroho & 22 & 30 & 22 & 12 & 9 & 9 & 1 & 4 \\
\hline 34 & Tri imam ariyanto & 22 & 30 & 22 & 16 & 9 & 9 & 1 & 4 \\
\hline 35 & Nurjamil muwahiddin & 22 & 30 & 28 & 16 & 9 & 9 & 4 & 9 \\
\hline 36 & Ridwan salam & 22 & 30 & 22 & 12 & 9 & 9 & 1 & 1 \\
\hline 37 & Faisal Pratama & 22 & 30 & 22 & 16 & 9 & 9 & 1 & 1 \\
\hline 38 & Irwan Setiawan & 22 & 30 & 22 & 16 & 9 & 9 & 1 & 1 \\
\hline 39 & Iwan Supandi & 22 & 30 & 22 & 16 & 9 & 9 & 1 & 1 \\
\hline 40 & Joko Susilo & 22 & 30 & 22 & 16 & 9 & 9 & 1 & 1 \\
\hline 41 & Khoirul Fajni & 22 & 30 & 22 & 16 & 9 & 9 & 4 & 4 \\
\hline 42 & Pandu Wicaksono & 22 & 30 & 22 & 16 & 9 & 9 & 1 & 4 \\
\hline 43 & Reza Pahlevy & 22 & 30 & 22 & 16 & 9 & 9 & 4 & 4 \\
\hline 44 & Agung Ruanda & 22 & 30 & 28 & 16 & 9 & 9 & 4 & 4 \\
\hline 45 & Alwi Fathoni & 22 & 30 & 22 & 16 & 9 & 9 & 1 & 1 \\
\hline 46 & Juandha Satria & 22 & 30 & 22 & 16 & 9 & 9 & 1 & 1 \\
\hline 47 & M-Andrifar & 22 & 30 & 22 & 16 & 9 & 9 & 1 & 1 \\
\hline 48 & Yogi Kameswara & 22 & 30 & 22 & 16 & 9 & 9 & 4 & 4 \\
\hline 49 & Aprilmadi Eka & 22 & 30 & 22 & 16 & 9 & 9 & 1 & 1 \\
\hline 50 & Sarwo Bimo Wahyudi & 22 & 30 & 22 & 12 & 9 & 9 & 4 & 4 \\
\hline 51 & Taufikurrahman & 22 & 30 & 22 & 16 & 9 & 9 & 1 & 1 \\
\hline 52 & Rizky Istianto $\mathrm{Aji}$ & 22 & 30 & 22 & 16 & 9 & 9 & 1 & 1 \\
\hline 53 & Muhamad Ridwan & 22 & 30 & 22 & 16 & 9 & 9 & 4 & 1 \\
\hline 54 & M. Sutra Dewangga & 22 & 30 & 28 & 16 & 9 & 9 & 1 & 4 \\
\hline 55 & Ach Rifadi & 22 & 30 & 22 & 16 & 9 & 9 & 1 & 4 \\
\hline 56 & Ahmad Soni Aji & 22 & 30 & 22 & 16 & 9 & 9 & 1 & 4 \\
\hline 57 & M. Handoko & 22 & 30 & 22 & 16 & 9 & 9 & 4 & 1 \\
\hline 58 & Roni Herpiansyah & 22 & 30 & 22 & 16 & 9 & 9 & 4 & 1 \\
\hline 59 & Rubiyanto Saputra & 22 & 30 & 22 & 16 & 9 & 9 & 4 & 1 \\
\hline 60 & Agus Haryanto & 22 & 30 & 22 & 16 & 9 & 9 & 4 & 1 \\
\hline
\end{tabular}

Penilaian total beban eksposur dapat dihitung dengan menggabungkan penilaian dari pengamat dan dari pekerja. Exposure Level (E) dihitungm berdasarkan persentase dari total aktual skor eksposur (X) dengan skor total maksimal (Xmax): Dimana:

$\mathrm{X}=$ Total skor, yang diperoleh dari penilaian postur (punggung+ bahu/lengan + pergelangan tangan + leher)

$\mathrm{X} \max =$ Total skor maksimum pada saat postur tubuh melakukan pekerjaan (punggung + bahu/lengan + pergelangan leher tangan + leher)

$\mathrm{X}$ max merupakan bilangan konstan untuk setiap jenis pekerjaan tertentu. Skor maksimal $(\mathrm{X} \max =162)$ diberikan ketika tubuh dalam keadaan posisi tubuh statis, duduk atau berdiri tanpa pengulangan dan beban yang relatif lebih rendah. Maksimum skor $(\mathrm{Xmax}=176)$ diberikan ketika pekerja melakukan penanganan manual seperti mengangkat, mendorong, menarik dan membawa beban.

Nilai action level atau level tindakan dari Metode QEC terdiri hingga 4 level tindakan dengan rentang presentase skor, tindakan yang perlu dilakukan dan hasil perhitungan total skor eksposur yang berbeda. Nilai level tindakan (action level) dari hasil perhitungan akhir skor eksposur ditunjukkan pada Tabel 3.

Tabel 3. Nilai Level Tindakan Perhitungan QEC

\begin{tabular}{cccc}
\hline Level Tindakan & $\begin{array}{c}\text { Persentase } \\
\text { Skor }\end{array}$ & Tindakan & $\begin{array}{c}\text { Total Skor } \\
\text { Exposur }\end{array}$ \\
\hline 1 & $0-40$ & Aman & $32-70$ \\
2 & $41-50$ & Diperlukan beberapa waktu ke depan & $71-88$ \\
3 & $51-70$ & Tindakan dalam waktu dekat & $89-123$ \\
4 & $71-100$ & Tindakan sekarang juga & $124-176$ \\
\hline \multicolumn{2}{l}{ Sumber: Li and Buckle, 1998 } &
\end{tabular}

Skor maksimal (Xmaks) yang digunakan sebesar 162, diberikan ketika tubuh masinis yang secara umum beraktifitas dalam keadaan posisi tubuh statis, yaitu dalam posisi duduk atau berdiri tanpa pengulangan dan beban yang relative lebih rendah. Berikut ialah hasil rekapitulasi perhitungan total skor eksposur dan level tindakan yang diperoleh.

Tabel 4. Rekapitulasi Total Skor Eksposure QEC

\begin{tabular}{|c|c|c|c|c|c|}
\hline No. & Nama Masinis & $\begin{array}{l}\text { Total skor } \\
\text { Elpposur }\end{array}$ & $\begin{array}{l}\text { Exposure } \\
\text { Level (\%) }\end{array}$ & $\begin{array}{c}\text { Level } \\
\text { Tindakan }\end{array}$ & Tindakan \\
\hline 1 & Kurdianto & 116 & $65,91 \%$ & 3 & Tindakan dalam waktu dekat \\
\hline 2 & Hendri S. & 119 & $67,61 \%$ & 3 & Tindakan dalam waktu dekat \\
\hline 3 & $\begin{array}{l}\text { Selamet } \\
\text { Yudiono }\end{array}$ & 116 & $65,91 \%$ & 3 & Tindakan dalam walktu dekat \\
\hline 4 & Juliandra Syarli & 109 & $61,93 \%$ & 3 & Tindakan dalam waktu dekat \\
\hline 5 & Amin Prayoga & 113 & $64,20 \%$ & 3 & Tindakan dalam waktu dekat \\
\hline 6 & Rifky Nuraziz & 119 & $67,61 \%$ & 3 & Tindakan dalam waktu dekat \\
\hline 7 & $\begin{array}{l}\text { Yusuf Faniz } \\
\text { Aiman }\end{array}$ & 110 & $62,50 \%$ & 3 & Tindakan dalam waktu dekat \\
\hline 8 & $\begin{array}{l}\text { Aumian } \\
\text { Aulia Zulfikar }\end{array}$ & 116 & $65,91 \%$ & 3 & Tindakan dalam waktu dekat \\
\hline 9 & M. Iqbal & 113 & $64,20 \%$ & 3 & Tindakan dalam waktu dekat \\
\hline
\end{tabular}




\begin{tabular}{|c|c|c|c|c|c|}
\hline 10 & Ari Marandika & 110 & $62,50 \%$ & 3 & Tindakan dalam waktu dekat \\
\hline 11 & Taufilk Hidayat & 100 & $56,82 \%$ & 3 & Tindakan dalam waktu dekat \\
\hline 12 & Ade Surya P. & 91 & $51,70 \%$ & 3 & Tindakan dalam waktu dekat \\
\hline 13 & Hafiz Daniswara & 128 & $72,73 \%$ & 4 & Tindakan sekarang juga \\
\hline 14 & Sealtiel Saragih & 113 & $64,20 \%$ & 3 & Tindakan dalam waktu dekat \\
\hline 15 & M.Rizqi Rosyid & 113 & $64,20 \%$ & 3 & Tindakan dalam waktu dekat \\
\hline 16 & Sobar M Fatoni & 110 & $62,50 \%$ & 3 & $\begin{array}{c}\text { Tindakan dalam waktu } \\
\text { dekat }\end{array}$ \\
\hline 17 & Andy Supriadi & 106 & $60,23 \%$ & 3 & Tindakan dalam waktu dekat \\
\hline 18 & Devi Yulianto & 109 & $61,93 \%$ & 3 & Tindakan dalam waktu dekat \\
\hline 19 & Agus Priyanto & 113 & $64,20 \%$ & 3 & Tindakan dalam waktu dekat \\
\hline 20 & Rizki Eka Firdaus & 122 & $69,32 \%$ & 3 & Tindakan dalam waktu dekat \\
\hline 21 & $\begin{array}{l}\text { Bachtiar } \\
\text { Mustakim }\end{array}$ & 122 & $69,32 \%$ & 3 & Tindakan dalam waktu dekat \\
\hline 22 & Setiawan Kuncoro & 116 & $65,91 \%$ & 3 & Tindakan dalam waktu dekat \\
\hline 23 & Feby Pratama & 113 & $64,20 \%$ & 3 & Tindakan dalam waktu dekat \\
\hline 24 & Ahmad Fajri & 116 & $65,91 \%$ & 3 & Tindakan dalam waktu dekat \\
\hline 25 & Egit Alpino & 122 & $69,32 \%$ & 3 & Tindakan dalam waktu dekat \\
\hline 26 & $\begin{array}{l}\text { Angga Bayu } \\
\text { Prawira }\end{array}$ & 116 & $65,91 \%$ & 3 & Tindakan dalam waktu dekat \\
\hline 27 & $\begin{array}{l}\text { Fathin } \\
\text { Fikriyansyah }\end{array}$ & 106 & $60,23 \%$ & 3 & Tindakan dalam waktu dekat \\
\hline 28 & Tham Saputro & 119 & $67,61 \%$ & 3 & Tindakan dalam waktu dekat \\
\hline 29 & Lustiono & 113 & $64,20 \%$ & 3 & Tindakan dalam waktu dekat \\
\hline 30 & Rio Pratama A & 122 & $69,32 \%$ & 3 & Tindakan dalam waktu dekat \\
\hline 31 & $\begin{array}{l}\text { M. Fajar } \\
\text { Mujadddid }\end{array}$ & 113 & $64,20 \%$ & 3 & Tindakan dalam waktu dekat \\
\hline 32 & Bambang Sujono & 122 & $69,32 \%$ & 3 & Tindakan dalam waktu dekat \\
\hline 33 & Heriyanto Hadi & 109 & $61,93 \%$ & 3 & Tindakan dalam waktu dekat \\
\hline 34 & Tri Imam & 113 & $64,20 \%$ & 3 & Tindakan dalam waktu dekat \\
\hline 35 & Muwahiddin & 127 & $72,16 \%$ & 4 & Tindakan sekarang juga \\
\hline 36 & Ridwan Salam & 106 & $60,23 \%$ & 3 & Tindakan dalam waktu dekat \\
\hline 37 & Faisal Pratama & 110 & $62,50 \%$ & 3 & Tindakan dalam waktu dekat \\
\hline $\begin{array}{l}38 \\
39\end{array}$ & $\begin{array}{l}\text { Irwan Setiawan } \\
\text { Iwan Supandi }\end{array}$ & $\begin{array}{c}110 \\
110\end{array}$ & $\begin{array}{l}62,50 \% \\
62,50 \%\end{array}$ & $3^{3}$ & $\begin{array}{l}\text { Tindakan dalam waktu dekat } \\
\text { Tindakan dalam waktu dekat }\end{array}$ \\
\hline 40 & Joko Susilo & 110 & $62,50 \%$ & 3 & Tindakan dalam waktu dekat \\
\hline 41 & Khoirul Fajni & 116 & $65,91 \%$ & 3 & Tindakan dalam waktu dekat \\
\hline 42 & Pandu Wicaksono & 113 & $64,20 \%$ & 3 & Tindakan dalam waktu dekat \\
\hline 43 & Reza Pahlevy & 116 & $65,91 \%$ & 3 & Tindakan dalam waktu dekat \\
\hline 44 & Agung Ruanda & 122 & $69,32 \%$ & 3 & Tindakan dalam waktu dekat \\
\hline 45 & Alwi Fathoni & 110 & $62,50 \%$ & 3 & Tindakan dalam waktu dekat \\
\hline 46 & Juandha Satria & 110 & $62,50 \%$ & 3 & Tindakan dalam waktu dekat \\
\hline 47 & M.Andrifar & 110 & $62,50 \%$ & 3 & Tindakan dalam waktu dekat \\
\hline 48 & Yogi Kameswara & 116 & $65,91 \%$ & 3 & Tindakan dalam waktu dekat \\
\hline 49 & Aprilmadi Eka & 110 & $62,50 \%$ & 3 & Tindakan dalam waktu dekat \\
\hline $\mathbf{5 0}$ & $\begin{array}{c}\text { Sarwo Bimo } \\
\text { Wahyudi }\end{array}$ & 112 & $63,64 \%$ & 3 & Tindakan dalam waktu dekat \\
\hline 51 & Taufikunahman & 110 & $62,50 \%$ & 3 & Tindakan dalam waktu dekat \\
\hline 52 & Rizky Istianto Aji & 110 & $62,50 \%$ & 3 & Tindakan dalam waktu dekat \\
\hline 53 & Muhamad Ridwan & 113 & $64,20 \%$ & 3 & Tindakan dalam walktu dekat \\
\hline 54 & $\begin{array}{c}\text { M. Sutra } \\
\text { Dewangga }\end{array}$ & 119 & $67,61 \%$ & 3 & Tindakan dalam waktu dekat \\
\hline 55 & Ach Rifadi & 113 & $64,20 \%$ & 3 & Tindakan dalam waktu dekat \\
\hline 56 & Ahmad Soni Aji & 113 & $64,20 \%$ & 3 & Tindakan dalam waktu dekat \\
\hline 57 & M. Handoko & 113 & $64,20 \%$ & 3 & Tindakan dalam waktu dekat \\
\hline 58 & Roni Herpiansyah & 113 & $64,20 \%$ & 3 & Tindakan dalam waktu dekat \\
\hline 59 & $\begin{array}{l}\text { Rubiyanto } \\
\text { Saputra }\end{array}$ & 113 & $64,20 \%$ & 3 & Tindakan dalam wakktu dekat \\
\hline 60 & Agus Haryanto & 113 & $64,20 \%$ & 3 & Tindakan dalam waktu dekat \\
\hline
\end{tabular}

Berdasarkan hasil perhitungan total skor akhir eksposur dan level tindakan yang diperoleh dari sampel yang bekerja ruang kemudi masinis masih beragam dan semua hasil level tindakan yang diperoleh menunjukkan 58 masinis mengalami eksposur level 3 dengan tindakan yang perlu dilakukan ialah tindakan dalam waktu dekat yang berarti tindakan perlu dilakukan secepatnya dan 2 masinis mengalami eksposur level 4 dengan tindakan yang perlu dilakukan ialah diperlukan tindakan sekarang juga.

Adapun penyebab adanya perbedaan tingkat eksposur skor segmen tubuh dan total keseluruhan pada jenis pekerjaan yang sama (masinis) di sebabkan oleh adanya penilaian persepsi individu seperti pertanyaan apakah masinis mengalami kesulitan dan apakah masinis mengalami setress saat mengemudikan KRL Commuter Line.

Tindakan yang perlu dilakukan yakni memperbaiki postur kerja dengan cara merancang fasilitas kerja yang ergonomis bagi operator yaitu masinis. Agar masinis dapat merasakan kenyamanan dan kemanan dalam melakukan pekerjaannya sehingga dapat mengurangi bahkan menghilangkan resiko kerja akibat postur kerja yang tidak baik yang disebabkan oleh fasilitas kerja. Rancangan fasilitas kerja yang dibuat berupa perbaikan fasilitas ruang kemudi masinis KRL Commuter Line menggunakan metode Ergonomi dan Antropometri yang memperhatikan dimensi tubuh yang terkait dengan rancangan fasilitas kursi dan kabin.

\section{Data Antropometri dan Persentil}

Data anthropometri diperoleh dengan cara melakukan pengukuran langsung menggunakan peralatan antropometer dan meteran tubuh terhadap sampel masinis KRL Commuter Line sebanyak 60 orang responden. Persentil adalah suatu nilai yang menyatakan bahwa persentase tertentu adalah suatu nilai yang menyatakan nilai dari sekelompok orang yang dimensinya sama dengan atau lebih rendah dari nilai tersebut. nilai persentil 5\%, 50\%, dan 95\% dipilih sebagai dasar penggunaan tiga prinsip umum dalam pengaplikasian data antropometri menurut Wignjosoebroto, 2003 yang telah dijelaskan di tinjauan pustaka. Rincian data persentil yang diolah dari data anthropometri masinis KRL Commuter Line adalah sebagai berikut:

Tabel 5. Data dimensi tubuh dan Persentil Masinis KRL Commuter Line

\begin{tabular}{ccccc}
\hline No. & Dimensi & P5\% & $\begin{array}{r}\text { Persentil } \\
\text { P50\% }\end{array}$ & P95\% \\
\hline 1 & Tinggi_badan & 165 & 168 & 170,31 \\
2 & Tinggi_mata & 151,785 & 154 & 156,05 \\
3 & Tinggi_duduk_normal & 86 & 88 & 90,31 \\
4 & Tinggi_mata_duduk & 72,475 & 74 & 76,5 \\
5 & Tinggi_bahu_duduk & 60,475 & 62 & 64,335 \\
6 & Tinggi_siku_duduk & 30,5 & 32 & 34,525 \\
7 & Tinggi_popliteal & 44 & 46 & 49 \\
8 & Tinggi_lutut & 51,475 & 53,25 & 56 \\
9 & Lebar_bahu & 40 & 43 & 45,835 \\
10 & Lebar_siku & 42,95 & 46,3 & 48,5 \\
11 & Lebar_ductuk & 34,99 & 37,5 & 41 \\
12 & Panjang_siku_kejari & 41,975 & 46 & 48,31 \\
13 & Panjang_pantat_kedengkul & 51,5 & 53,5 & 55 \\
14 & Pantat_popliteal & 46,5 & 48,4 & 50 \\
15 & Panjang_telapak_kaki (sepatu) & 25,5 & 28,5 & 31,5 \\
16 & Lebar_telapak_kaki (sepatu) & 11 & 13 & 15 \\
17 & Jangkuan_tangan_atas & 209,475 & 213 & 216 \\
18 & Jangkauan_tangan_kedepan & 69 & 70,5 & 73,5 \\
19 & Rentang_siku_ke_siku & $\mathbf{8 1 , 4 7 5}$ & 83 & $\mathbf{8 5 , 5 2 5}$ \\
20 & Rentang_tangan & 162 & 164 & 166 \\
\hline Sumber: Hasil Pengolahan, 2017 & & & \\
& & &
\end{tabular}

\section{Model Lingkungan kabin Aktual}

Pembuatan model lingkungan kerja dibuat dengan dengan mengguanakan software Autocad Mechanical 2015. 


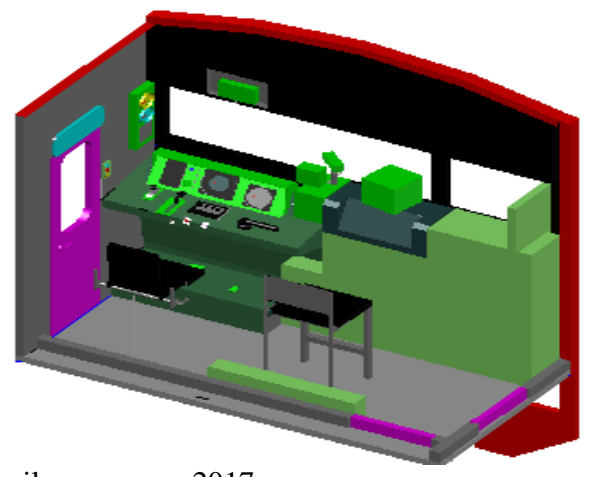

Sumber : Hasil rancangan, 2017

Gambar 1. Desain Aktual KRL JR East 2015

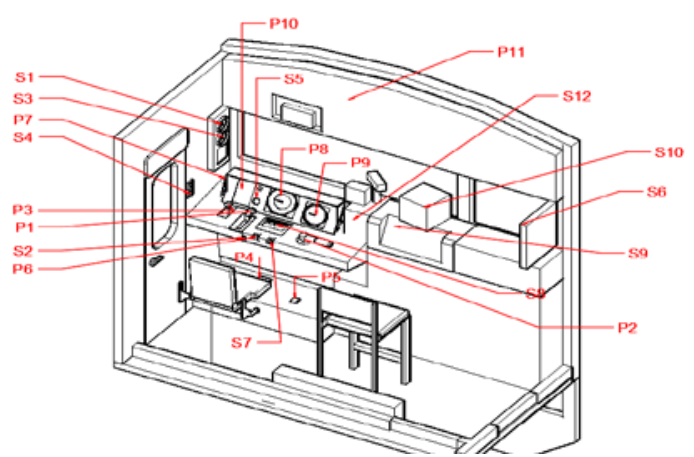

Sumber : Hasil rancangan, 2017

Gambar 2. Tata letak Kendali Kontrol dan pemantau Desain Aktual

Tabel 6. Keterangan Letak Instrumen Kendali Kontrol dan Pemantau

\begin{tabular}{cccc}
\hline Kode & $\begin{array}{c}\text { kendali control dan pemantau } \\
\text { utama }\end{array}$ & Kode & $\begin{array}{c}\text { kendali control dan pemantau } \\
\text { Pendukung }\end{array}$ \\
\hline P1 & Throttle / Tuas kecepatan & S1 & $\begin{array}{c}\text { manometer / tegangan kenpressor } \\
\text { tappercuren / tombol reset daya }\end{array}$ \\
P2 & Tuas rem & S2 & tegangan batre \\
P3 & Reverser / pengatur posisi maju, & S3 & power panthograf \\
netral, atau mundur & S4 & Switch Kepala KRL \\
P4 & deatman pedal & S5 & Pengatur suhu kereta \\
P5 & pedal lampu sinyal & S6 & tombol pintu \\
P6 & suling / klakson & lampu jalan \\
P7 & pesawat radio kereta & S7 & S8 \\
P8 & speedometer & S9 & tombol-tombol lampu dan AC \\
P9 & daya/ tegangan listrik & display suhu dan tekanan udara \\
P10 & layar fungsi (kegagalan) & S10 & dalam ruangan \\
P11 & emergency brake & S11 & Layar Pemantau CCTV \\
& & S12 & Indikator Rute \\
\hline
\end{tabular}

Sumber: Hasil rancangan, 2107

\section{Model Lingkungan Kabin Usulan}

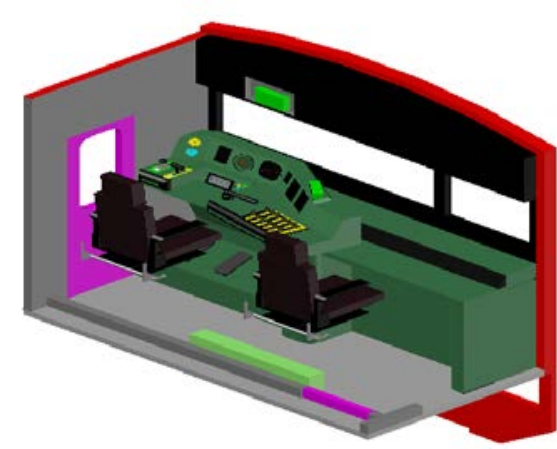

Sumber : Hasil rancangan, 2017

Gambar 3. Ruang Kendali Masinis KRL Commuter Line Usulan
Proses perancangan desain usulan dibuat dengan mempertimbangkan ukuran dimensi ruang kemudi yang cukup kecil. Perancangan menggunakan dasar

meode data antropometri masinis yang telah diperoleh dan kajian ergonomi yang diperoleh dari beberapa referensi yang berkaitan dengan Human Factor, Lokomotif dan safety

Peracangan kabin kendali dan tata letak instrumen di dengan penempatan Primary Control and Display di depan masinis, dan penempatan Secondary Control and Display ditempatkan di sisi kiri dan kanan Primary Control and Display. Penempatan tersebut dibuat tidak jauh dari jangkauan tangan masinis dengan desain sedikit melengkung mengitari bagian depan badan masinis. Penempatan seperti ini dapat dikatakan cukup ergonomis karena dapat mengoptimalkan daya jangkau (tangible range according) masinis dalam menggunakan alat kendali utama dan pembantu. Sehingga masinis dapat mengoperasikan kereta seorang diri tanpa kesulitan.

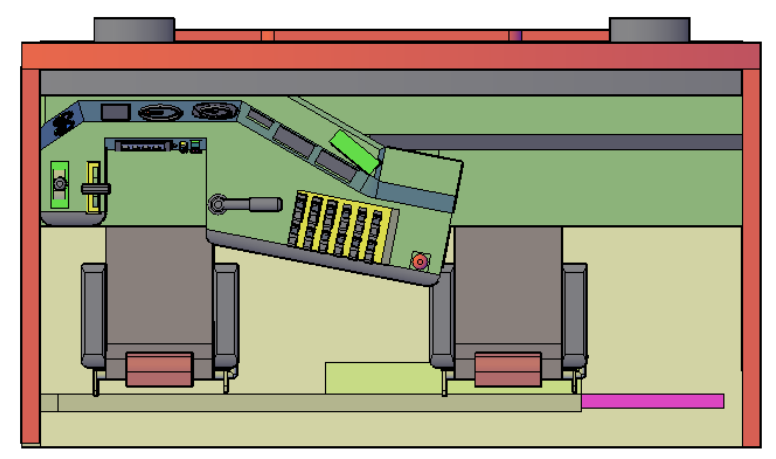

Sumber : Hasil Rancangan, 2017

Gambar 4. Model Kendali Rancangan Usulan Berdasarkan Metode Tangible Range According

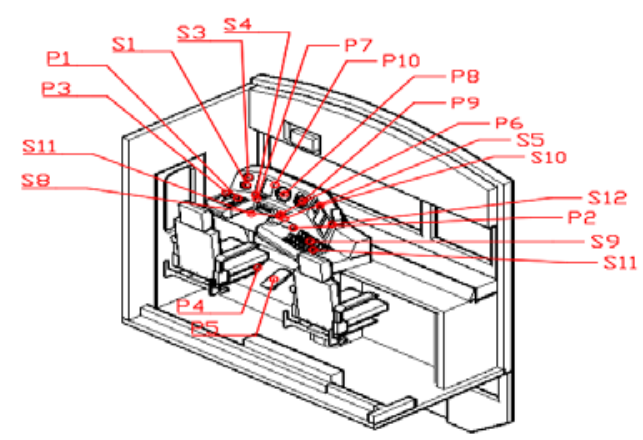

Sumber : Hasil Rancangan, 2017

Gambar 5. Letak Instrumen Kendali Kontrol dan Pemantau Desain Usulan

Tabel 7. Keterangan Letak Instrumen Kendali Kontrol dan Pemantau 


\begin{tabular}{|c|c|c|c|}
\hline Kode & $\begin{array}{c}\text { kendali control dan pemantau } \\
\text { utama }\end{array}$ & Kode & $\begin{array}{l}\text { kendali control dan pemantau } \\
\text { Pendukung }\end{array}$ \\
\hline P1 & Throttle / Tuas kecepatan & S1 & manometer / tegangan kenpressor \\
\hline $\mathrm{P} 2$ & Tuas rem & S2 & tappercuren / tombol reset daya \\
\hline P3 & $\begin{array}{l}\text { Reverser / pengatur posisi maju, } \\
\text { netral, atau mundur }\end{array}$ & S3 & tegangan batre \\
\hline P4 & deatman pedal & \$4 & power panthograf \\
\hline P5 & pedal lampu sinyal & S5 & Switch Kepala KRL \\
\hline P6 & suling / klakson & S6 & Pengatur suhu kereta \\
\hline P7 & pesawat radio kereta & S7 & tombol pintu \\
\hline P8 & speedometer & S8 & lampu jalan \\
\hline P9 & daya / tegangan listrik & s9 & tombol-tombol lampu dan AC \\
\hline P10 & layar fungsi (kegagalan) & S10 & $\begin{array}{l}\text { display suhu dan tekanan udara } \\
\text { dalam ruangan }\end{array}$ \\
\hline \multirow[t]{2}{*}{ P11 } & emergency brake & S11 & Layar Pemantau CCTV \\
\hline & & S12 & Indikator Rute \\
\hline
\end{tabular}

\section{SIMPULAN}

Dari pengukuran dan perhitungan dapat disimpulkan bahwa

1. Dengan metode QEC diperoleh total skor eksposur level yang dialami masinis saat mengoperasikan KRL Commuter Line ada pada rentan $62-69 \%$

atau berada pada level 3 yaitu berada pada golongan tingkat eksposur tinggi. Tingkat eksposur pada segmen tubuh punggung, bahu, tangan, dan leher ada pada kategori sedang, sehingga diperlukan tindakan perbaikan perlu dilakukan secepatnya.

2. Hasil analisa terhadap ukuran dimensil aktual yang digunakan pada KRL JR East 205 menunjukkan bahwa ukuran kursi yang digunakan saat ini kurang sesuai dengan ukuran tubuh masinis. Desain kursi yang menempel pada dinding dan cukup sederhana menyebabkan kursi terlalu jauh dengan kabin tuas pengendali. Selain itu penempatan instrumen pengontrol dan pemantau pendukung di nilai kurang ergonomis karena di letakan terlalu jauh dari jangkauan dan penglihatan masinis sehingga masinis harus mengubah postur duduk dan penglihatan untuk menjangkau instrumen tersebut. Kondisi tersebut membentuk postur duduk yang buruk dan dapat mengakibatkan cedera pada tubuh masinis.

3. Desain yang diusulkan dengan mempertimbangkan ukuran ruangan yang cukup sempit dengan mempertimbangkan tingkat prioritas dan keharmonisan instrument pengendali menggunakan metode tangle according atau kemampuan jangkauan tangan.

\section{DAFTAR PUSTAKA}

Bridger, R.S. 1995, Introduction to Ergonomics, McGraw-Hill, Singapura

Erlangga, Djodi. 2017, Usulan Perancangan Kabin Masinis KRL Commuter Line yang Ergonomis Menggunakan Metode Virtual Environment. Skripsi Mahasiswa Teknik
Industri UPN "Veteran” Jakarta.

Li, G. dan Buckle, P. 1998, A Practical Method For The Assesment Of Work: Related Musculoskeletal Risks, Taylor \& Francis, Chicago

Stevenson, M.G. 1989, Principles Of Ergonomics, Center for Safety ScienceUniversity Of NSW, Australia

Nurmianto, Eko 1991, Ergonomi, konsep dasar \& aplikasinya, Guna Widya, Jakarta 